Louisiana State University

LSU Digital Commons

Faculty Publications

Department of Geography \& Anthropology

2003

\title{
Neo-Environmental Determinism, Intellectual Damage Control, and Nature/Society Science
}

Andrew Sluyter

Louisiana State University, asluyter@lsu.edu

Follow this and additional works at: http://digitalcommons.lsu.edu/geoanth_pubs

Part of the Anthropology Commons, and the Geography Commons

\section{Recommended Citation}

Andrew Sluyter, Neo-Environmental Determinism, Intellectual Damage Control, and Nature/Society Science, Antipode 35 (2003) 813-17.

This Article is brought to you for free and open access by the Department of Geography \& Anthropology at LSU Digital Commons. It has been accepted for inclusion in Faculty Publications by an authorized administrator of LSU Digital Commons. For more information, please contact gcoste1@lsu.edu. 


\title{
- עer \\ Neo-Environmental Determinism, Intellectual Damage Control, and Nature/Society Science
}

\author{
Andrew Sluyter \\ Department of Geography and Anthropology, The Louisiana State University, \\ Baton Rouge, LA, USA; asluyter@1su.edu
}

In Guns, Germs, and Steel (1997; hereafter GGS), Jared Diamond grandiosely claims that the current differentiation of the world into rich and poor regions has a simple explanation that everyone else but him has overlooked: differences in environment have determined the different "fates of human societies" ( pp 3, 15, 25-26). Such a revival of the environmental determinist theory that the horrendous living conditions of millions of people are their natural fate would not ordinarily merit scholarly discussion, but since $G G S$ won a Pulitzer Prize, many people have begun to believe that Diamond actually offers a credible explanation of an enormously deleterious phenomenon. $G G S$ therefore has such great potential to promote harmful policies that it demands vigorous intellectual damage control. As a contribution to that effort, this essay not only demonstrates that $G G S$ is junk science but proposes a model of the process through which so many people, including scientists who should know better, have come to think so much of such a pernicious book and, more generally, of neoenvironmental determinism.

Imposed brevity precludes adding much to James Blaut's (1999) catalog of the specious logic and erroneous facts that riddle the subarguments of $G G S$ and that by cumulative effect alone render it junk science. The following two examples merely illustrate the character of such errors.

First, factual error: Diamond claims that the precolonial peoples of western North America were hunters, fishers, and gatherers because that region had no domesticable plant species, but he neglects to consider evidence that when Europeans arrived in the region, people from California to British Columbia were in the process of domesticating many native plant species (pp 356, 367). He blatantly ignores facts that prominent ethnographers published many years ago and that the current literature reiterates (Lawton, Wilke, and Mason 1976;

(C) 2003 Editorial Board of Antipode.

Published by Blackwell Publishing, 9600 Garsington Road, Oxford OX4 2DQ, UK and 350 Main Street, Malden, MA 02148, USA 
Deur 1997, 2002). Specifically, Julian Steward (1933) reported seventy years ago that precolonial Paiute in California planted taboose (yellow nut-sedge, Cyperus esculentus) for its copious tubers and used canals to irrigate it and other plants. Around the same time, Franz Boas (1934) published evidence that precolonial Kwakiutl in British Columbia planted tliksam (silverweed, Potentilla pacifica) for its abundant rhizomes and used rock-walled fields to cultivate it and other plants. Colonization interrupted those and other practices that would otherwise have resulted in fully domesticated native plants through the usual selective pressures involved in planting and harvesting (Rindos 1984).

Second, logical error: Diamond argues that the environments of the four "continents" he defines (Eurasia, the Americas, Africa, and Australia) determined the availability of domesticable animals on each continent, but he contradicts himself logically by also arguing that people drastically reduced that availability on at least one continent. Specifically, he claims in one subargument that Eurasia's large surface area determined that it had many more domesticable animals than any of the other continents (pp 161-163). Yet he claims in another subargument that around 11,000 BC the First Peoples of the Americas probably hunted to extinction many Pleistocene "mammal species that might otherwise have later been domesticated" ( $p$ 47). If the American case is the exception to his determinist rule, then, at one out of four continents, it is a big enough exception to falsify rather than prove that rule.

Why do people such as the Pulitzer judges forgive the vast accumulation (see Blaut 2000:149-171) of such factual and logical errors in the subarguments, which by itself renders $G G S$ absurd? Perhaps they believe the subarguments can be salvaged through revision? Perhaps they very desperately desire a simple overall explanation for a complex phenomenon?

Unfortunately for those still clinging to Diamond's promise of a simple explanation, $G G S$ also suffers from a structural problem that will require much more to fix than fiddling with the subarguments. Based on his discussion of epistemology, Diamond clearly realizes that categorical associations (eg all members of category $\mathrm{X}$ are also members of category $\mathrm{Y}$ ) are not sufficient to explain complex historical phenomena with nonrecurring, ramifying interactions among a great number of dynamic elements with emergent properties (pp 421-424). His own standards, therefore, do not allow him simply to begin and end his explanation of such a phenomenon with such an association: namely, a category of continents that have large surface areas and latitudinal major axes spatially correlates with a category of societies that have great wealth and power relative to a category of societies that spatially correlates with a category of continents that have small 
surface areas and meridional major axes (pp 29, 405-408). To demonstrate the causal significance of that association, he needs to explicate the historical process through which his environmental categories actually caused his social categories. Otherwise, his claim that Eurasians, "especially those still living in Europe and eastern Asia [viz Japan], plus those transplanted to North America, dominate the modern world in wealth and power" ( $p$ 15) because Eurasia is the only largelatitudinal continent relies entirely on circular reasoning: Eurasia's unique environment has caused the G-8's dominance, the proof being Eurasia's unique environment and the G-8's dominance.

Yet, despite being well aware that he must fully explicate the processes-what he calls "chains of causation"- through which, over thousands of years of inexorable cause and effect, environment supposedly determined the dominance of the G- 8 , Diamond never does (pp 86-87). Instead, he leaves a glaring gap of five centuries between the initial European invasion of the Americas and the phenomenon he claims to explain, apparently finding colonization and (post)colonization processes irrelevant to understanding the current global map of wealth and power. Commendably, he does push "back the chain of historical causation" and address environmental processes that others would dismiss as irrelevant ( $p$ p 9-10). But in order to demonstrate the veracity of a cause-and-effect explanation, every link in the chain-from putative first cause right up to final effectrequires serious attention, and the absolute gap of five centuries in a chain already compromised by the cumulative effects of numerous factually and logically weak links renders Diamond's overall argument structurally unsound. The only rationale he offers for leaving the gap is the blatant fallacy (Blaut 1993) that by 1492, the world was already divided between non-Eurasian tribes with stone weapons and Eurasian empires with steel weapons who directly and unproblematically bestowed power on their G-8 descendants ( $p 16)$. I predict that any attempt by Diamond to span the gap would, if done with factual and logical integrity, only further disprove the causal significance of his categorical association.

As GGS stands, then, its argument relies on a categorical argument that is disturbingly similar to the Eurocentric, teleological thinking of the racists that Diamond so laudably condemns (pp 18-22). The main difference is that instead of genes determining wealth and power, environment determines genes plus wealth and power. Thus, according to Diamond, Africa's environment determined that "Africa Became Black" hand-in-hand with becoming poor (pp 376-401).

A more important issue than the intellectual failings of $G G S$, however, is how so many people have come to think so much of it. The recent proliferation of scientific and popular publications (eg Hausmann 2001; Landes 1998; Robson 2002; Sachs, Mellinger, and Gallup 2001) 

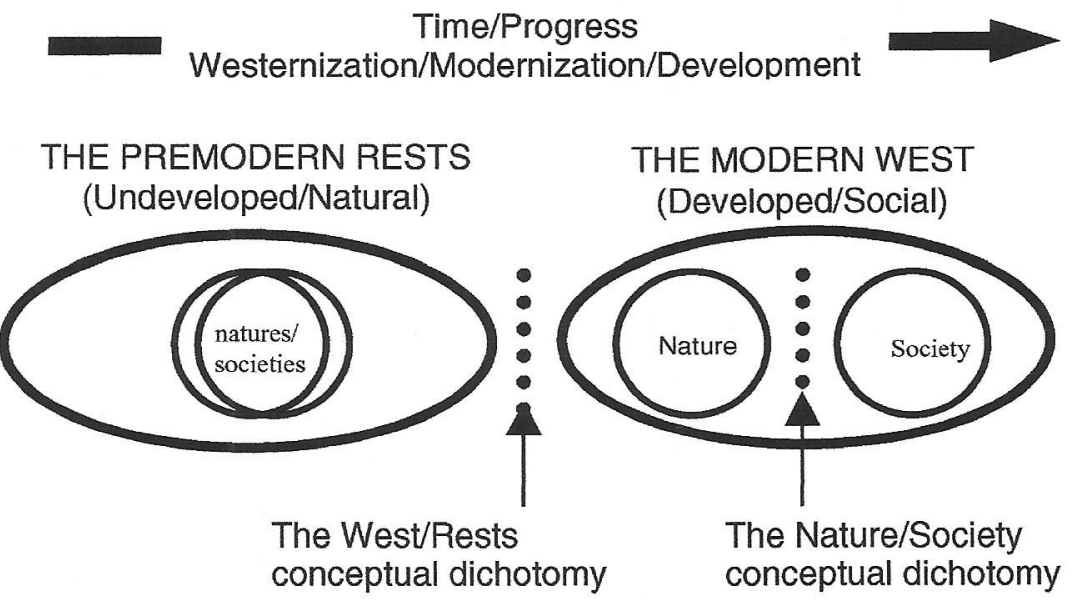

Figure 1: View from the West (Sluyter nd: figure 1:modified from Latour 1993:figure 4.2)

that rely on the same sort of faulty categorical thinking suggests a relationship between neo-environmental determinism and the broad intellectual transformation that historians of science, such as Bruno Latour (1993), argue is taking place.

Latour's model of how the modern West and its sciences emerged together helps to explain how geographers first adopted and then abandoned environmental determinism and how some are now reviving it (Sluyter 2002:215-227). As the two conceptual dichotomies that define the West qua West consolidated in the 19th century (Figure 1), explorer geographers were describing the last of the precolonial landscapes of the Rests, while the definition of a normal science was beginning to demand an explanatory intellectual core. Both trends rendered exploration obsolete, and the early academic geographers responded by promising to use environmental determinism to explain variation among landscapes. But as the nature/society dichotomy strengthened, it dictated that scientific disciplines have an explanatory intellectual core focused on nature or society, environmental determinism became anathema, geographers abandoned any concerted attempt at naturesociety explanations, and most of them realigned with either the natural or the social sciences. Now the two dichotomies are beginning to crumble in the face of the staggering, natural/social boomerang effects of modernization (eg global climate change) that demonstrate that it will never free society from the constraints of nature or individuals from the constraints of society-the long-promised "double emancipation" (Sluyter nd). In the short run, as scientists from both sides of the nature/society dichotomy scramble to deal with modernization's boomerang effects by integrating research on nature 
and society, opportunists are able to achieve some renown by reviving environmental determinism as a quick and dirty integration of the natural and social sciences. In the long run, a mature nature/society science will lose all patience for such neo-environmental determinists.

\section{Acknowledgments}

Although the views expressed in this essay do not necessarily reflect those of the people acknowledged, I thank Mark Cowell and Chris Merrett for organizing this forum, William Denevan and Suzanne Moon for offering feedback on drafts, and the late James Blaut for discussions of Guns, Germs, and Steel.

\section{References}

Blaut J (1993) The Colonizer's Model of the World: Geographical Diffusionism and Eurocentric History. New York: Guilford Press

Blaut J (1999) Environmentalism and Eurocentrism. Geographical Review 89:391-408

Blaut J (2000) Eight Eurocentric Historians. New York: Guilford Press

Boas F (1934) Geographical Names of the Kwakiutl Indians. New York: Columbia University Press

Deur D (1997) Was the Northwest coast agricultural? Ecological, archaeological, and ethnographic evidence. Paper presented at the Annual Meeting of the American Association for the Advancement of Science, Seattle, WA, 15 February

Deur D (2002) Rethinking precolonial plant cultivation on the northwest coast of North America. The Professional Geographer 54:140-157

Diamond J (1997) Guns, Germs, and Steel: The Fates of Human Societies. New York: W W Norton

Hausmann R (2001) Prisoners of geography. Foreign Policy 122:44-53

Landes D (1998) The Wealth and Poverty of Nations: Why Some Are So Rich and Some So Poor. New York: W W Norton

Latour B (1993) We Have Never Been Modern. Cambridge, MA: Harvard University Press

Lawton H W, Wilke P J and Mason W M (1976) Agriculture among the Paiute of Owens Valley. Journal of California Anthropology 3:13-50

Rindos D (1984) The Origins of Agriculture: An Evolutionary Perspective. San Diego: Academic Press

Robson J (2002) A few words on why Africa is the way it is. The Vancouver Sun 28 June:A16

Sachs J B, Mellinger A D and Gallup J L (2001) The geography of poverty and wealth. Scientific American 284(3):70-5

Sluyter A (2002) Colonialism and Landscape: Postcolonial Theory and Applications. Lanham, MD: Rowman and Littlefield

Sluyter A (nd) Scientific geography and the modern nature/society and West/rest dichotomies. Manuscript available from author

Steward J H (1933) Ethnography of the Owens Valley Paiute. University of California Publications in American Archaeology and Ethnology vol 33, no 3. Berkeley: University of California Press 